\title{
The Making of a Midwestern Catholicism: Identities, Ethnicity, and Catholic Culture in Iowa City, 1840-1940
}

\author{
Michael J. Pfeifer
}

ORAL TRADITION holds that in the nineteenth century, Irish families at St. Mary's Catholic Church in Iowa City rented pews on the west side of the church while German families preferred pews on the east side. That was because the high altar in Iowa City's oldest Catholic church is flanked on the left by a statue of St. Patrick, the patron saint of Ireland, and on the right by a statue of St. Boniface, the patron saint of German Catholicism. ${ }^{1}$

\begin{abstract}
A 2014-2015 State Historical Society of Iowa Research Grant supported the research and writing of this article. The author thanks Marvin Bergman and several anonymous readers for their comments on a draft of this article. The author is particularly indebted to the late Rev. John P. Boyle for inspiring and encouraging the interest in the history of ethnic Catholicism in Iowa City that would germinate years later in the research for this article. Any errors herein are the author's alone.

1. "History of Saint Mary's Church," http:/ / www.icstmary.org/history.php, accessed 9/22/2015; Joseph Fuhrmann, Souvenir of the Diamond Jubilee of St. Mary's Church, Iowa City, Iowa (Iowa City, 1916), 23, 28. I sought to access archival records at the Diocese of Davenport but was informed that no relevant records existed for the period under consideration; I am grateful to Tyla Cole for her assistance. An effort to search archival materials at Iowa City parishes yielded only sacramental records; I thank Rachel Santos at St. Mary's Church for her aid. Fortunately, numerous extant primary sources, including newspaper sources and published clergy's correspondence, as well as Joseph Fuhrmann's richly detailed if randomly organized 1916 St. Mary's parish historywhich often quotes primary sources verbatim, often without attributionenable the reconstruction of Iowa City's nineteenth-century ethnic Catholicism.
\end{abstract}


Even though the story may oversimplify ethnic divisions and identity among Catholics in a developing midwestern town in the nineteenth century, it does convey the important truth that national origin and subsequent diasporic identity formation played crucial roles in the first century of Catholic culture in the American Midwest. Indeed, the story of contending altar statues of ethnic patron saints is all that remains within the parish's collective memory of what were highly contested battles among three Catholic ethnic groups-Germans, Irish, and Bohemians (Czechs)-over space, clerical leadership, devotional styles, and the nature of lay involvement in what was Iowa City's only Catholic parish for several decades in the mid-nineteenth century. ${ }^{2}$

In recent decades a lively scholarly literature has sought to determine the nature of the American Catholic experience and the historical factors that have shaped it. That literature shows that American Catholic institutions developed from a delicate interplay of a hierarchical international religious culture centered in Rome with an American republican culture strongly influenced by Protestant and secular critiques of Catholicism. ${ }^{3}$ Historians of American Catholicism have also begun to more fully understand that the history of U.S. Catholics, like that of many American religious groups, did not begin and end at water's edge. Catholics - perhaps especially (although hardly exclusively) among U.S. religious groups - long sustained strong transatlantic connections, not only with Rome but well into the twentieth century as well with coreligionists in centers of European Catholic culture such as Ireland, France, Belgium, the AustroHungarian Empire, and Bavaria. In their broadest context, then,

2. For an important theoretical discussion of the dynamics of diasporic religious identity, see Jonathan Z. Smith, Map Is Not Territory: Studies in the Histories of Religions (Leiden, 1978), xiv.

3. For important interpretations of the history of American Catholicism, see, for example, John Tracy Ellis, American Catholicism, 2nd ed. (Chicago, 1969); James Hennessey, American Catholics: A History of the Roman Catholic Community in the United States (New York, 1983); Jay P. Dolan, The American Catholic Experience: A History from Colonial Times to the Present (Garden City, NY, 1985); idem, In Search of an American Catholicism: A History of Religion and Culture in Tension (New York, 2003); John T. McGreevy, Catholicism and American Freedom: A History (New York, 2003); James T. Fisher, Communion of Immigrants: A History of Catholics in America (New York, 2007); Jon Gjerde, Catholicism and the Shaping of Nineteenth-Century America, ed. S. Deborah Kang (New York, 2012). 
regional American Catholic cultures and a larger American Catholicism developed over time as transnational Catholic immigrants ecclesiastically linked to and by Rome in a hierarchical, authoritarian, and communalistic "universal church" creatively adapted their devotional and ideological practices in an American context that emphasized republicanism, religious liberty, and individualistic capitalism. ${ }^{4}$

The study of the history of American Catholicism has been a robust field of inquiry in recent decades, producing conceptually rich social, cultural, and intellectual histories that have broken free from the limitations of traditional church history with its sometimes narrow institutional and ecclesiastical focus. Yet at times the macro focus of recent American Catholic scholarship has almost looked past the local, parish level at which most American Catholics have actually experienced their religious culture(s) since the early nineteenth century. Moreover, while the heavily Catholic urban northeast has received significant attention from historians, the substantially Catholic Midwest has received less attention, with the important exception of the urban Rust Belt's multiethnic Catholicism. ${ }^{5}$ At the state level,

4. For arguments for a less nationalistic and more transnational history of American Catholicism, particularly in light of the centrality of international relationships to the structure of Catholicism, see John T. McGreevy, "Bronx Miracle," American Quarterly 52 (2000), 412-13, 438 fn19; Peter R. D'Agostino, Rome in America: Transnational Catholic Ideology from the Risorgimento to Fascism (Chapel Hill, NC, 2004). For an essential interpretation of German Catholics in the Midwest that emphasizes transatlantic connections along with diasporic identity formation, see Kathleen Neils Conzen, "Immigrant Religion and the Republic: German Catholics in Nineteenth-Century America," GHI Bulletin no. 35 (Fall 2004), 43-56.

5. A useful overview of the development of Catholicism in the urban and rural Midwest can be found in Stephen J. Shaw, "The Cities and the Plains, a Home for God's People: A History of the Catholic Parish in the Midwest," in Jay P. Dolan, ed., The American Catholic Parish: A History from 1850 to the Present, vol. 2, The Pacific, Intermountain West, and Midwest States (New York, 1987), 277-401. For a more recent overview, see Jay P. Dolan, "Catholics in the Midwest: Final Revised Draft," https://www3.nd.edu/ jdolan/midwest.html, accessed 9/14/ 2015. For urban Rust Belt Catholicism, see John T. McGreevy, Parish Boundaries: The Catholic Encounter with Race in the Twentieth-Century Urban North (Chicago, 1996); Robert Orsi, "The Center Out There, in Here, and Everywhere Else: The Nature of Pilgrimage to the Shrine of Saint Jude, 1929-1965," Journal of Social History 25 (1991), 213-32; Steven M. Avella, This Confident Church: Chicago Catholicism, 1940-1965 (South Bend, IN, 1992); idem, In the Richness of the Earth: A 
the history of some of Iowa's key Catholic institutions has received effective treatment from historians, but the social history of Iowa Catholicism at the parish level has received comparatively little attention. ${ }^{6}$

This article seeks to remedy these gaps by using Iowa City's history of transnational, multiethnic Catholic cultures to trace the complex and varied origins of a midwestern regional Catholic culture. Iowa can in a sense be seen as indicative of the Catholic experience in the lower Midwest, where diverse ethnic Catholic enclaves scattered across a largely rural landscape that also attracted large numbers of worshipers from various Protestant denominations, especially Methodists, Lutherans, and Congregationalists. With the exception of more densely Catholic northeast Iowa, much of the Hawkeye State displays this lower midwestern pattern of Catholic enclaves within a majority Protestant religious landscape. ${ }^{7}$

Located at the approximate juncture point of densely Catholic northeast Iowa and sparsely Catholic central and southern Iowa, Iowa City provides an excellent setting to trace the formation of a regional Catholic culture rooted in plural ethnic diasporas and transnational connections. In the antebellum and early postbellum periods, the town was unusual for its relatively modest size in encompassing the diverse, heterogeneous character of nineteenth-century midwestern Catholicism, including significant numbers of Irish, German, and Bohemian (Czech) Catholics.

History of the Archdiocese of Milwaukee, 1843-1958 (Milwaukee, 2002); Leslie Woodcock Tentler, Seasons of Grace: A History of the Catholic Archdiocese of Detroit (Detroit, 1990). For the Catholic experience in a predominantly Protestant portion of the the rural upper Midwest in the early twentieth century, see Leslie Woodcock Tentler, "'A Model Rural Parish': Priests and People in the Michigan 'Thumb,' 1923-1928," Catholic Historical Review 78 (1992), 413-30.

6. George William McDaniel, "Catholic Action in Davenport: St. Ambrose College and the League for Social Justice," Annals of Iowa 55 (1996), 239-72; idem, A Great and Lasting Beginning: The First 125 Years of St. Ambrose University (Davenport, 2006).

7. For a discussion of the factors shaping the historical geography of Iowa Catholicism, see Madeleine M. Schmidt, Seasons of Growth: History of the Diocese of Davenport, 1881-1981 (Davenport, 1981), 98-105. For an overview of religiosity in nineteenth-century Iowa, including the efforts of Catholics, Methodists, Congregationalists, Presbyterians, Quakers, and Jews, see Dorothy Schwieder, Iowa: The Middle Land (Ames, 1996), 109-18. 
Amid the centrifugal pressures initially exerted by their diversity, Iowa City's Catholics experienced in miniature larger processes that would play out across the Midwest and among American Catholics more generally.

Uneasily integrated for several decades in a single parish housing the town's three significant ethnic Catholic communities, St. Mary's parish would fracture in favor of ethnic separatism, the formation of distinct ethnic parishes, in the latter decades of the nineteenth century. Yet in the early to midtwentieth century, assimilative and Americanization pressures exerted by both the larger society and church leaders would cut the other way, undermining older particularistic ethnic identities, eventually rendering ethnic Catholicism a quaint memory. Indeed, Iowa City's relatively cosmopolitan nature as a small and slowly growing university town may have hastened this process, at least after 1900 (in contrast, for example, with communities of German Catholics elsewhere in the rural and urban Midwest that persisted in their distinctiveness until the 1930s and sometimes after). ${ }^{8}$

According to census data, Iowa City numbered 1,250 in 1850 and then mushroomed to 5,214 by 1860 , but did not surpass 10,000 until 1910, and by 1940 had reached only 17,182. Iowa City's relatively modest size and population stasis until the early twentieth century constrained the formation of Catholic parishes and the building of Catholic churches and gave relations between its multiethnic Catholics a certain intensity. On the other hand, the university town's cosmopolitanism may have conversely served to hasten the decline of ethnic particularism after $1900 .{ }^{9}$

\footnotetext{
8. Kathleen Neils Conzen, "German Catholics in America," in Michael Glazier and Thomas J. Shelley, eds., The Encyclopedia of American Catholic History (Collegeville, MN, 1997), 582.

9. Iowa State Data Center, "Total Population for Iowa's Incorporated Places, 1850 2000, www.iowadatacenter.org/datatables/PlacesAll/plpopulation18502000.pdf, accessed 9/19/2015. It is important to note in a consideration of the role of Catholic culture in nineteenth-century Iowa City that some young Protestant women attended St. Agatha's Academy and that Mercy Hospital, attended by the Sisters of Mercy, served as the de facto university hospital until the 1880s. I am grateful to an anonymous reader for this important point.
} 
A CATHOLIC PRESENCE in Iowa City dates to its inception as territorial capital in 1841 and the labors of Fr. Samuel Mazzuchelli, an intrepid Dominican friar born in Milan in 1806 and assigned in 1828 by Cincinnati Bishop Edward Fenwick to serve as a missionary priest for the vast Northwest Territory. Mazzuchelli had professed vows to the Dominicans in Milan as the order was recovering from a period of suppression and internal disorder under Napoleonic and then Austrian rule. After the young Milanese friar arrived in the United States, he served farflung Catholic communities around the Great Lakes, particularly Native Americans and French and mixed ancestry Métis fur traders. Fr. Mazzuchelli, often anglicized as "Matthew Kelly," also administered the sacraments to lead miners, many of them Irish Catholics, as they arrived at Galena and Dubuque in the 1830s. ${ }^{10}$

After the establishment of the diocese of Dubuque in 1837 and of Iowa Territory in 1838, Mazzuchelli assisted Mathias Loras, the first bishop of Dubuque, in rapidly organizing Catholic congregations and building churches in territorial settlements, including Davenport and Burlington. Perpetuating Catholic ties linking the Mississippi valley to France that stemmed to the colonial era, Loras and other French émigré priests in territorial Iowa participated in a postrevolutionary Catholic revivalism that sought to restore French society to a universalistic organic Catholic order following the iconoclastic, anticlerical French Revolution. Loras had been born in Lyon in 1792 to a prominent family; seeking to purge the city, France's third largest, of the ancien régime, revolutionaries had condemned and executed the future Dubuque prelate's father and several of his aunts and uncles. ${ }^{11}$

10. Mary Nona McGreal, Samuel Mazzuchelli: American Dominican (Notre Dame, IN, 2005), 9-175. McGreal offers a comprehensive, scholarly, and highly sympathetic treatment of Mazzuchelli's life. For Mazzuchelli's missions among Natives, his disputes over funding with federal Indian agents that favored Protestants, and his opposition to treaty violations and Indian removal, see McGreal, Samuel Mazzuchelli, 93, 96, 99, 168-69; and Kenneth E. Colton, "Father Mazzuchelli's Iowa Mission," Annals of Iowa 21 (1938), 310, 313-14.

11. B. C. Lenehan, "Right Rev. Mathias Loras, D.D., First Bishop of Dubuque," Annals of Iowa 3 (1899), 577-84; Michael Pasquier, Fathers on the Frontier: French Missionaries and the Roman Catholic Priesthood in the United States, 1789-1870 (New York, 2010). Pasquier's analytically rich treatment of French missionary priests in the nineteenth-century trans-Appalachian West provides essential context for understanding clerics such as Mathias Loras. 


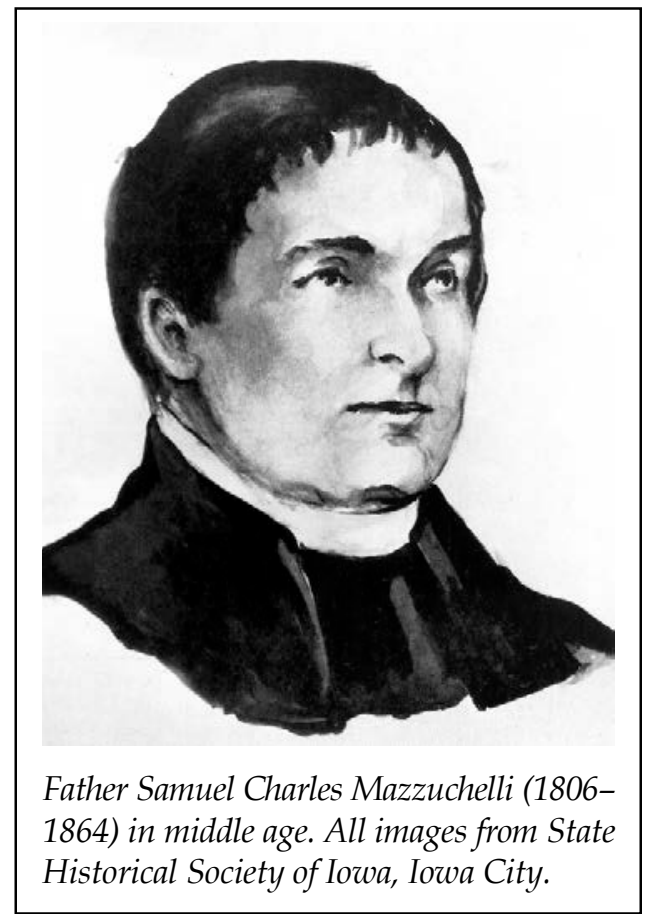

The European missionary priests Mazzuchelli and Loras played key roles in establishing a Catholic congregation in Iowa Territory's new capital city. Mazzuchelli, like other Catholics in the early decades of the nineteenth century, often spoke and wrote of the consonance of Catholicism with American republican ideology (even as anti-Catholic thinkers articulated the opposite). In the winter of 1840-41 he had cultivated ties to territorial legislators in Burlington while the legislature met in St. Paul the Apostle Church, which the Milanese friar had established. Mazzuchelli recalled in his memoirs that Iowa City arose in a matter of months on a site that "was in June of 1839 an uninhabited solitude covered with trees." 12

12. Samuel Mazzuchelli, The Memoirs of Father Samuel Mazzuchelli, O.P., trans. Mary Benedicta Kennedy (Chicago, 1915), accessible at www.fathermazzuchellisociety.org/memoirs-of-father-samuel-mazzuchelli/, accessed 9/14/2015; all quotations in this and subsequent paragraphs are from chaps. 33 and 34 . Mazzuchelli's memoirs were written and published in Italian as he visited Milan in 1843. 


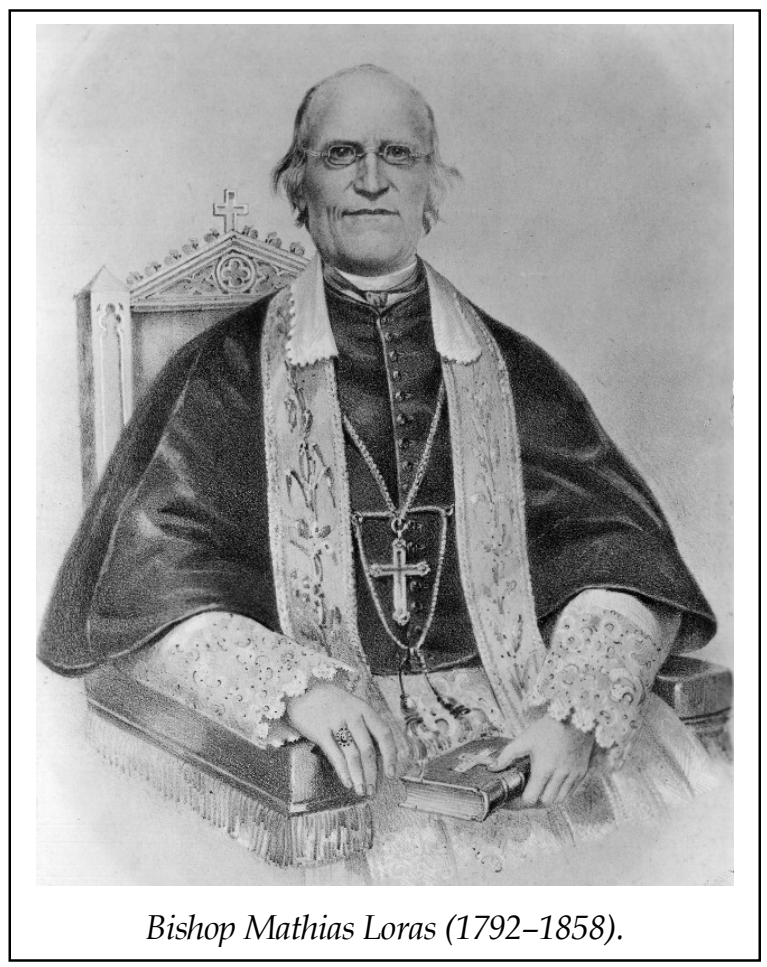

In December 1840, drawing on a legislative enactment reserving lots for churches in the new capital city, Mazzuchelli, with a security of $\$ 2,000$, acquired two lots for a Catholic church. The Italian priest noted that representatives of nascent Protestant congregations, including "The Primitive Methodists, the Methodist Episcopalians, the Presbyterians, [and] the Unitarians," eagerly did the same, creating a vibrant religious marketplace in the infant territorial capital. Mazzuchelli celebrated the first Mass in Iowa City on December 20 at the house of a "German mechanic," Ferdinand Habestroh, "not far from the State House," with 28 of the town's 30 Catholic settlers attending. He then preached Iowa City's "first dogmatic sermon" in "the Hall of a small hotel." 13

On July 12, 1841, Loras laid the cornerstone of St. Mary's Church, which was dedicated to the Assumption of the Blessed

13. Ibid. 


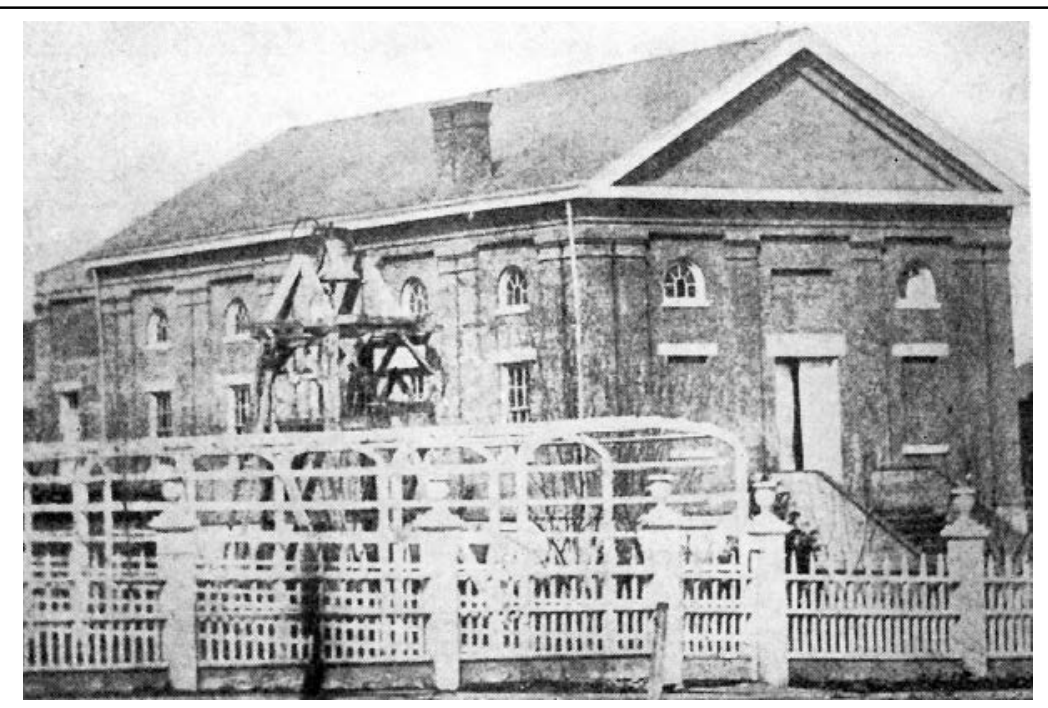

The original St. Mary's Church in Iowa City.

Mary. Mazzuchelli explained that "as she is the Patroness of the Diocese it was fitting that to her should be dedicated the first church of Iowa's Capital." At the dedication, Mazzuchelli preached on the consistency of Catholic worship with American republican government, addressing "the large gathering present on the subject of the Religious and even political advantages resulting from the practice of Divine worship, and that the truths of the Gospel are the basis of true liberty and true patriotism." The church was constructed by the spring of 1843 , with a basement subdivided for a rudimentary dwelling for the priest and a school. At the land sales in Dubuque, Loras purchased land on the outskirts of Iowa City to be used for a Catholic cemetery. Looking ahead, Mazzuchelli believed that 500 German Catholics already lived in the environs of Iowa City and that they, along with Irish settlers and "converts" would within a few years "form a large parish, and one of some importance also, in the matter of the influence exerted by any city wherein reside the members of the Legislature, the Governor and State Officials." 14

14. Ibid.; Fuhrmann, Souvenir of the Diamond Jubilee of St. Mary's Church, 8-11; McGreal, Samuel Mazzuchelli, 188. For Mazzuchelli's attempt to synthesize Catholicism and American republicanism, see Mary Nona McGreal, "Samuel 
FROM THE 1840s through the mid-1850s, as Bishop Loras published letters in Irish and German Catholic newspapers in eastern and midwestern cities seeking to lure Catholic immigrants to Iowa, St. Mary's predominantly Irish and German congregants would be served by French and Irish priests. For much of the nineteenth century, the American Catholic church would rely on clergy recruited from Europe, for whom the concrete realities of American life often existed in tension with their participation in an ultramontane revival centered in Europe that renewed emphasis on papal, Roman-centered authority, stressed the prestige and power of priests as religious specialists intermediating between the laity and the sacred, and rejuvenated an array of devotions such as the Sacred Heart of Jesus that emphasized identification with a suffering Christ. ${ }^{15}$

In his early years leading the diocese Loras had recruited French priests and seminarians to Dubuque. Several of those priests, including Anthony Pelamourgues, Anthony Godfert, and B. M. Poyet, would serve at St. Mary's in the 1840s. Despite their shared nativity, Loras and his French clergy had contentious relations. Pelamourgues, who was the founding and longtime pastor at St. Anthony's Church in Davenport, from 1839 until 1868, objected that Loras was creating parishes and churches more rapidly than the Catholic population and the available clergy warranted. Like many footloose Catholic clerics

Mazzuchelli: Participant in Frontier Democracy," Records of the American Catholic Historical Society of Philadelphia 87, no. 1 (1976), 99-114; and idem, Samuel Mazzuchelli, 305-19. For an overview of efforts among Catholics, such as Baltimore Bishop John Carroll, in the early American republic to reconcile Catholicism with republicanism and other Enlightenment values, see Jay P. Dolan, "The Search for an American Catholicism," Catholic Historical Review 82 (1996), 174-78; idem, In Search of an American Catholicism, 13-45. Mazzuchelli's synthesis of "Catholicity" and American republicanism, which he sometimes defended against anti-Catholic polemicists around the Old Northwest, may have reflected a more optimistic, Enlightenment-inflected view of the potential for an American Catholicism than would be found among ultramontane Catholic thinkers in the United States later in the antebellum period. For the ultramontane revival in the United States, see McGreevy, Catholicism and American Freedom, 27-30.

15. Pasquier, Fathers on the Frontier, 11-18; McGreevy, Catholicism and American Freedom, 27-30; Mark G. McGowan, The Waning of the Green: Catholics, the Irish, and Identity in Toronto, 1887-1922 (Montreal, 1999), 91-93. 
in the nineteenth-century United States, Anthony Godfert, who in 1844 became the resident pastor in Iowa City, would seek better opportunities by departing Loras's authority in 1846 to serve in the new diocese of Milwaukee under Bishop John Martin Henni, a Swiss German. ${ }^{16}$

Revs. J. P. McCormick and Mathias Hannon, Irish-born pastors at St. Mary's in the early 1850s, embodied the disciplined folk piety created by a "devotional revolution" that transformed Irish Catholicism in the years before and after the famine and large-scale Irish immigration to the United States. ${ }^{17}$ Decades later, in 1891, Hannon vividly recalled an intrepid cleric's existence in Iowa City, lodging at a boarding house "directly south from the old State House" (before a formal rectory was built in 1854), as well as saying Mass and attending sick calls at missions and stations all around the Hawkeye State, which was filling in with white settlement west of the Cedar River as far south as Mt. Pleasant and as far to the north and west as Fort Dodge. 18

Like many Catholic priests in the antebellum United States, Iowa City clerics contended against the anti-Catholic, nativist backlash that followed significant Irish and German Catholic immigration. In Iowa City, sectarian disputation over school funding and the use of the Protestant Bible in common schools spilled into the election for School Funds Commissioner, with Methodists publicly opposing a Catholic candidate and Catholics burning Bibles distributed by Methodists. St. Mary's priest B. M. Poyet and Alexander Bushnell, a Methodist minister and Whig Party operative, engaged in vitriolic exchanges in Iowa City newspapers, with Bushnell alleging Catholic anti-republican designs on the county school fund and noting the weakness of religious liberty in papal-dominated areas of Catholic Europe.

16. McGreal, Samuel Mazzuchelli, 175-81; Fuhrmann, Souvenir of the Diamond Jubilee of St. Mary's Church, 11-15. For the letter in which Pelamourgues criticized Loras for building too many churches in new settlements with small numbers of Catholics, see Schmidt, Seasons of Growth, 53.

17. Emmett Larkin, “The Devotional Revolution in Ireland, 1850-1875," American Historical Review 77 (1972), 625-52.

18. Fuhrmann, Souvenir of the Diamond Jubilee of St. Mary's Church, 15-19 (quotation from p. 17). 
Poyet parried by denouncing Bushnell's anti-Catholic bigotry and invoking the patriotism of French Catholic American Revolutionary War hero Marquis de Lafayette. ${ }^{19}$

OVER THE NEXT DOZEN YEARS, St. Mary's slipped into crisis, as the parish's sizable numbers of Irish and Germans and lesser but nonetheless significant numbers of Bohemians (Czechs) disputed over whether their ethnic communities were adequately and equitably served by the parish's polyglot Catholicism. The seeds of ethnic factionalism developed as Iowa City's Catholic population grew in size and complexity in the late antebellum era. The 1850 census had tallied 152 German-born and 86 Irish-born residents in Johnson County; the 1860 census enumerated 1,407 born in Germany, 1,258 in Ireland, 820 in the Austrian Empire (including Bohemians), and 891 born in yet other countries. ${ }^{20}$

In 1853 an Austrian Jesuit priest, Franz Xavier Weninger, led a mission in Iowa City that yielded six converts and culminated with the erection of a 40-foot cemetery cross. For three decades beginning in 1848 Weninger conducted approximately 800 missions among Catholic communities around the United States, inspiring the formation and construction of many new parishes and churches, especially among Germans. In Iowa City, his visit led German Catholics to begin organizing a German parish, designating land in the northeastern part of the city. Germans at St. Mary's had organized a short-lived German school during Fr. Hannon's pastorate, and the German-language school revived in 1857 under his successor, Fr. Mathias Michels, a priest born in Luxemburg and trained in France. Michels sought to serve Bohemian Catholics at St. Mary's by bringing in a Czech Redemptorist Father, Francis Krubil, in 1856 to lead a mission for Bohemian parishioners. Yet Irish parishioners disputed Michels's

19. For the exchanges between the Revs. Bushnell and Poyet, see Iowa City Republican, 4/24/1850, 5/8/1850, and 5/22/1850. For anti-Catholicism and sectarian debates in American political discourse in the nineteenth century, see Gjerde, Catholicism and the Shaping of Nineteenth-Century America; and Jenny Franchot, Roads to Rome: The Antebellum Protestant Encounter with Catholicism (Berkeley, CA, 1992).

20. Schmidt, Seasons of Growth, 77. 
efforts to manage the needs of the parish's three distinct ethnic communities, asserting that he favored the Germans, who by this time may have been outnumbered by the rapidly growing number of Irish Catholics in Iowa City. ${ }^{21}$

The contention between ethnic communities worshiping uncomfortably under the same roof at St. Mary's reflected significant differences in traditions and styles of Catholicism carried from countries of origin. Those different traditions and styles were transformed in diasporic communities that evolved in response to American conditions. At the same time, those communities remained in communication with their national/religious homelands via devotional books, the ethnic press, clergy traveling back and forth, and newly arrived immigrants.

Irish Catholic immigrants (virtually all of them English speakers) practiced a recently forged "disciplined folk piety" that refracted centuries of Celtic mysticism and was shaped by searing experiences of famine and English colonial oppression and bigotry. These Irish Catholics readily assented to ultramontane clerical authority and the steady diminution of lay authority in the antebellum American church as Irish bishops (such as New York's John Hughes) faced off against hostile, nativist Protestant Americans. In terms of liturgy and devotions, Irish Catholics tended to prefer a relatively simple and austere form of worship and especially valued the sacramental act of confessing sins to a priest. ${ }^{22}$

21. Fuhrmann, Souvenir of the Diamond Jubilee of St. Mary's Church, 19-20; Theodosius Plassmeyer, "The Early Church in Iowa City," Iowa Catholic Historical Review 9 (February 1936), 31. For Franz Xavier Weninger, see Conzen, "German Catholics in America," 576. Some sources list Fr. Mathias Michels as "Mathias Michael."

22. Larkin, "The Devotional Revolution in Ireland"; David W. Miller, "Irish Catholicism and the Great Famine," Journal of Social History 9 (1975), 81-98; Michael P. Carroll, "Re-Thinking Popular Catholicism in Pre-Famine Ireland," Journal for the Scientific Study of Religion 34 (1995), 354-65; Jay P. Dolan, The Irish Americans: A History (New York, 2010); idem, "Immigrants in the City: New York's Irish and German Catholics," Church History 41 (1972), 354-68, esp. 364; Shaw, "The Cities and the Plains, a Home for God's People," 305-7; Lawrence J. McCaffrey, "Irish Textures in American Catholicism," Catholic Historical Review 78 (1992), 1. For conflict between Irish and Germans at St. Alphonsus Parish in antebellum New York City and the creation of national parishes identified with ethnic communities that spoke foreign languages as a way to avert such conflict, see Dolan, "Immigrants in the City," 360, 362. 
For their part, German Catholics, shaped by a sense of their social disadvantage vis-à-vis Protestants within German society and by the embattled status of Catholicism in Prussia, strongly emphasized lay participation in church governance (kirchenrat). That often led to conflict with bishops (particularly Irish ones in the northeastern United States) and priests who sought to exert what lay Germans regarded as undue control over lay trustees and worshipers. German Catholic immigrants strongly emphasized parochial schools, with particular stress on transmitting German Catholic culture through instruction in German. German Catholics also valued an elaborate baroque communalistic devotional style that included "processions and pilgrimages, confraternities, rich orchestral music and richly embellished churches" as well as a vernacular style stemming from Enlightenment Catholicism that emphasized robust congregational singing (lustige Gesang). German Catholic immigrant ideals were most fully realized in enclaves in upper midwestern states such as Wisconsin and Minnesota, where the German immigrants organized their own national parishes (parishes organized by nationality or ethnicity rather than the "territorial" parishes that became the norm by the early twentieth century) and through their votes controlled local polities, including public school systems. ${ }^{23}$

Czechs (along with German Bohemians), by contrast, emigrated from Bohemian lands ruled by the Austro-Hungarian empire. Catholic churches in Bohemia reflected older feudal arrangements and were funded by noble patrons or from property held by the church, with fairly minimal lay support such as gifts for clergy or Mass stipends. As they sought to maintain a rich baroque devotional style rooted in Bohemian Slavic traditions, Czech Catholic immigrants to the American Midwest struggled

23. Shaw, "The Cities and the Plains, a Home for God's People," 306-15; Emmet H. Rothan, The German Catholic Immigrant in the United States (Washington, DC, 1946); Colman J. Barry, The Catholic Church and German Americans (Milwaukee, 1953); Conzen, "German Catholics in America," 571-83 (quotation from p. 578); Kathleen Neils Conzen, "Immigrant Religion in the Public Sphere: The German Catholic Milieu in America," in Wolfgang Helbich and Walter Kamphoefner, eds., German-American Immigration and Ethnicity in Comparative Perspective (Madison, WI, 2004), 69-116. Rothan, The German Catholic Immigrant, 66-69, treats early German Catholic settlement in Iowa. Rothan found 18 German Catholic churches with priests in residence in Iowa by 1860. 
with unfamiliar expectations of lay funding for parishes as well as the lay initiative required to negotiate with parish and diocesan officials, especially in light of the paucity of Czech-speaking priests in the United States. ${ }^{24}$

In 1858 a young German-born priest, William Emonds, arrived in Iowa City to lead St. Mary's parish. Despite his leadership, German and Bohemian parishioners alleged that Irish and English-speaking worshipers were receiving favorable treatment to their detriment. Sacramental records at St. Mary's from this tumultuous period, written in Latin by Fr. Emonds, document the fluctuating ethnic mix at St. Mary's. Concentrations of baptisms of Irish, German, and Bohemian infants ebbed and flowed over time with the ethnic politics that engulfed the parish. ${ }^{25}$

In 1862 Fr. Franz Xavier Weninger led another mission in Iowa City and encouraged Germans and Bohemians to form their own parish. In response, most of the Germans, along with the Bohemians, departed an overcrowded St. Mary's. Receiving permission from Clement Smyth, the Irish-born bishop who had succeeded Mathias Loras, the Germans and Bohemians who left St. Mary's built a small church dedicated to St. Francis Xavier at Brown and Johnson Streets in northern Iowa City. A Bohemian priest, Adolph Spocek, served as pastor there for a year. After Spocek left, the parish lacked a resident priest for a year, until April 1864, when Smyth assigned Capistran Zwinge, a Franciscan from Westphalia, Germany, who had arrived with other German Franciscans in central Illinois in the late 1850s to establish institutions to serve German Catholics in the Midwest. Soon the parish and its new pastor purchased a building for a rectory and made arrangements to bring in the Sisters of Charity of the Blessed Virgin Mary to run a school. Zwinge and his parishioners then sought to raise funds to pay off the debt incurred in establishing a parish plant that now stretched over a city block. ${ }^{26}$

24. Joseph Cada, Czech-American Catholics, 1850-1920 (Lisle, IL, 1964), 9-10.

25. Book II of Baptisms, 1860-1878, St. Mary's Church, Iowa City.

26. Plassmeyer, "The Early Church in Iowa City," 21-23; William Henry Perrin, ed., History of Effingham County (Chicago, 1883), 255. Bishop Clement Smyth, a Trappist, was born in County Clare, in 1810, and came to Iowa with the founding of New Melleray Abbey in Dubuque County in 1849. Schmidt, Seasons of Growth, 91-92. Some sources list Adolph Spocek as "Adolph Spacek." 
In the year he administered the sacraments at St. Francis Xavier, Zwinge, in letters to his Franciscan superiors, documented the travails of his congregation and a longer context of internecine struggles among Catholic ethnic groups in Iowa City. A letter dated June 13, 1864, lamented a general spiritual "indifference" among Catholics in Iowa City and bemoaned the small size of his church, "which in reality is the first story of a common dwelling." At the same time, he happily noted that many rural residents came in to town for Sunday Mass, some from as many as ten miles away, and he observed that the parish had conducted an open procession on the feast day of Corpus Christi, a favorite ritual of German Catholics. ${ }^{27}$

A letter dated June 1, 1865, rehearsed the history of ethnic Catholic factionalism in Iowa City and recounted the quick falling out of Germans and Bohemians at St. Francis Xavier under his predecessor, primarily because of differences in how the two groups supported the parish financially, distinctions that stemmed to the contrasting Catholic cultures that Germans and Bohemians brought to Iowa from Europe. Zwinge's candid analysis indulged a German's condescending distaste for Czech culture but also a pastoral concern for both German and Bohemian Catholics.

Principally the Germans built the first Catholic Church in Iowa City. The Irish, however, increased more rapidly in number and the Germans formed the minority, until they became only an appendage to the parish. Father Michael [Michels] favored the Germans more than the Irish, and that displeased the latter. Father Emonds, (the present pastor, a Westphalian) sided with the English, and totally incurred the displeasure of the Germans, who never did harmonize well with the English. The Germans at the advice of Rev. Weninger, then separated from the original parish and built a new church. Their pastor, a Bohemian, united the German and Bohemian elements in one congregation. But since the Bohemians would neither contribute to the church, nor support the pastor, and since the Germans almost exclusively were obliged to maintain the priest, the latter, greatly disappointed in his own countrymen, inclined more to the German element. This, of course,

27. Fr. Capistran Zwinge to Fr. Commissary Mathias, 6/13/1864, translated from German and quoted in Plassmeyer, "The Early Church in Iowa City," 24-25. 
provoked the Bohemians, and many unpleasant frictions arose. These circumstances may have induced the pastor to take his final sudden leave. I may remark, the Bohemians here, as is known fact, do pay very poorly for their church and the support of the priest. They want frequent dances even though they have not a shirt on their back. ... Just the day before, a trial in court took place on account of some fighting-fray at their last dance for which they were heavily fined. ${ }^{28}$

Zwinge was not sanguine about reconciliation among the distinct ethnic Catholic communities in Iowa City. He noted that he had tried to get the Czech Catholics to come back to St. Francis Xavier but with only limited success. He doubted that Germans and Bohemians could be successfully united in a parish in Iowa City.

After my arrival, I tried to win the Bohemians back to church. But they replied, that the Germans had declared, that they would throw the Bohemians out. I assured them that I would not tolerate that, and that they might come without fear. The Germans were not pleased; but I obliged them to give the Bohemians at least standing room. Since that time, some of the Bohemians come to our church. Up to date, however, they neither rented a seat, nor probably contributed a single quarter of a dollar. Some others frequent the English church. Most of them, I should judge, stay at home. These are our present conditions. An attempt to unite the Germans and Bohemians, I consider a mere illusion. Perhaps a union with the Irish could be effected more easily. But also in this case, insurmountable difficulties will present themselves. For the Irish have their own church and, as long as Fr. Emonds is in charge, he would never permit it. ${ }^{29}$

On June 17, 1865, Zwinge's Franciscan superior in Teutopolis, Illinois, recalled him from Iowa City. In his time at St. Francis Xavier, Zwinge had enumerated 136 baptisms and 7 conversions. Zwinge's departure imperiled the future of the German Catholic parish on Iowa City's north side. Despite letters from parishioners pleading for the return of Zwinge or the assignment of another Franciscan, and even a visit from a delegation of parish

28. Fr. Capistran Zwinge to Fr. Commissary Mathias, 6/1/1865, translated from German and quoted in Plassmeyer, "The Early Church in Iowa City," 31-32.

29. Ibid. 
representatives, John Sueppel and John Xanten, to Teutopolis, the German Franciscans in Illinois could spare no priests for Iowa City, and the parish was only intermittently staffed by diocesan priests. ${ }^{30}$ As one plaintive letter from parish trustees lamented, betraying a German Catholic sense of grievance at their purported second-class status (behind the privileged Irish) within American Catholicism, "We were so happy and contented and would no more believe that German Catholic parishes in America were treated by bishops as step-children. But all of a sudden we were plunged into this present sad and disconsolate condition so that, deprived of a pastor, we must look forward to a future that holds out to us little encouragement." 31 The parish closed in February 1867, and its congregants returned to St. Mary's. Much of St. Francis Xavier Church was destroyed in a fire in $1869 .{ }^{32}$

The compelled reunification of diverse ethnic Catholic communities at St. Mary's in the late 1860s was visually epitomized by the diorama of ethnic Catholic unity bringing together saints Patrick and Boniface, patrons of Irish and German Catholicism, respectively, astride the high altar at the new St. Mary's Church that was dedicated on August 15, 1869. Meanwhile, on the east side of the new St. Mary's, gallery murals depicted four key Bohemian saints: Wenceslaus (Vaclav), his grandmother Ludmila, John of Nepomuk, and Adalbert. ${ }^{33}$ But unity at St. Mary's was short-lived.

In the last decades of the nineteenth century, ethnic factionalism among Catholics in Iowa City led down the same pathway taken elsewhere by heterogeneous ethnic Catholic communities in the rural and urban United States, including the Midwest: the creation of separate parishes predicated largely along ethnic lines. The difficult, fragile attempt to fashion a universal Catholic

30. Plassmeyer, "The Early Church in Iowa City," 34-37.

31. Letter of 6/24/1865, translated from German and quoted ibid., 34.

32. Fuhrmann, Souvenir of the Diamond Jubilee of St. Mary's Church, 23, 86; Plassmeyer, "The Early Church in Iowa City," 21-37.

33. Fuhrmann, Souvenir of the Diamond Jubilee of St. Mary's Church, 26-30; Richard Lalor, Celebrating Thanks! A History of Saint Mary of the Assumption Parish, Iowa City, Iowa (Iowa City, 1993), 11-12. 


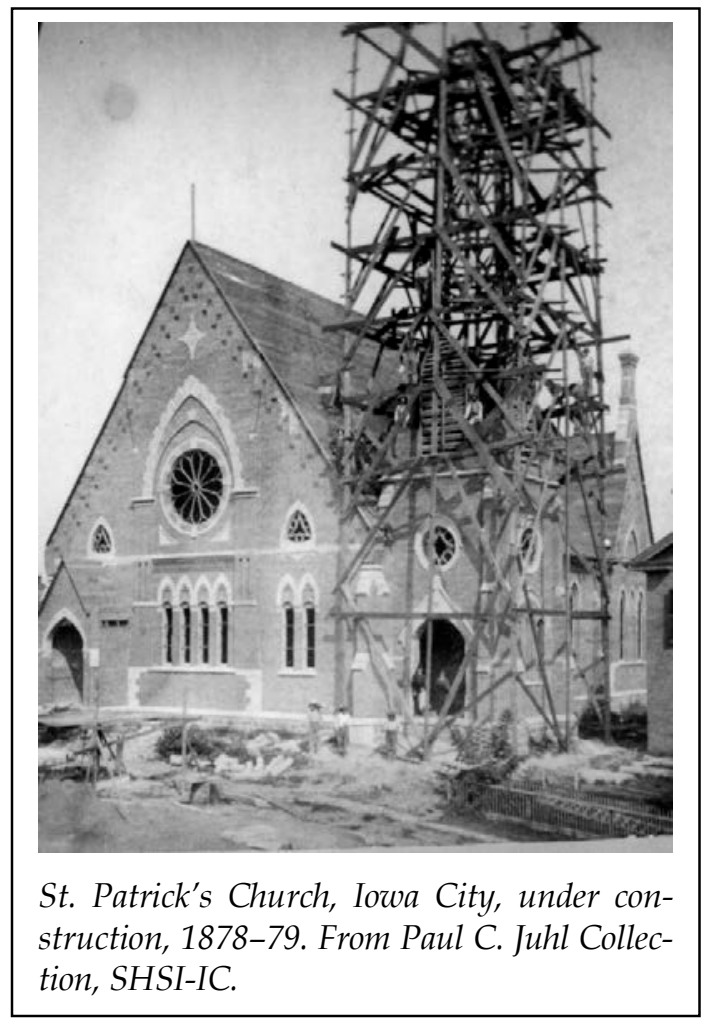

community in the university town, no longer the state's capital city (which had shifted to Des Moines in 1857), was abandoned in favor of congregations organized along lines of ethnic solidarity, a pattern that would hold until the early to mid-twentieth century. ${ }^{34}$

IN 1873 many Irish Americans, seeking their own ethnic parish, free of the difficult, pluralistic compromises that the shared multiethnic devotional space at St. Mary entailed after the return of

34. The impulse to ethnic separatism/segregation was hardly limited to Catholics in Iowa City, although it had different contexts in Protestant churches with a less constrained sense of lay initiative and with a less elaborated church hierarchy. In the late nineteenth century, Iowa City was home to German Lutheran and German Methodist congregations in addition to English-speaking ones, and to two Methodist Episcopal congregations, one for whites and one for African Americans. Iowa Citizen, 8/26/1892. 


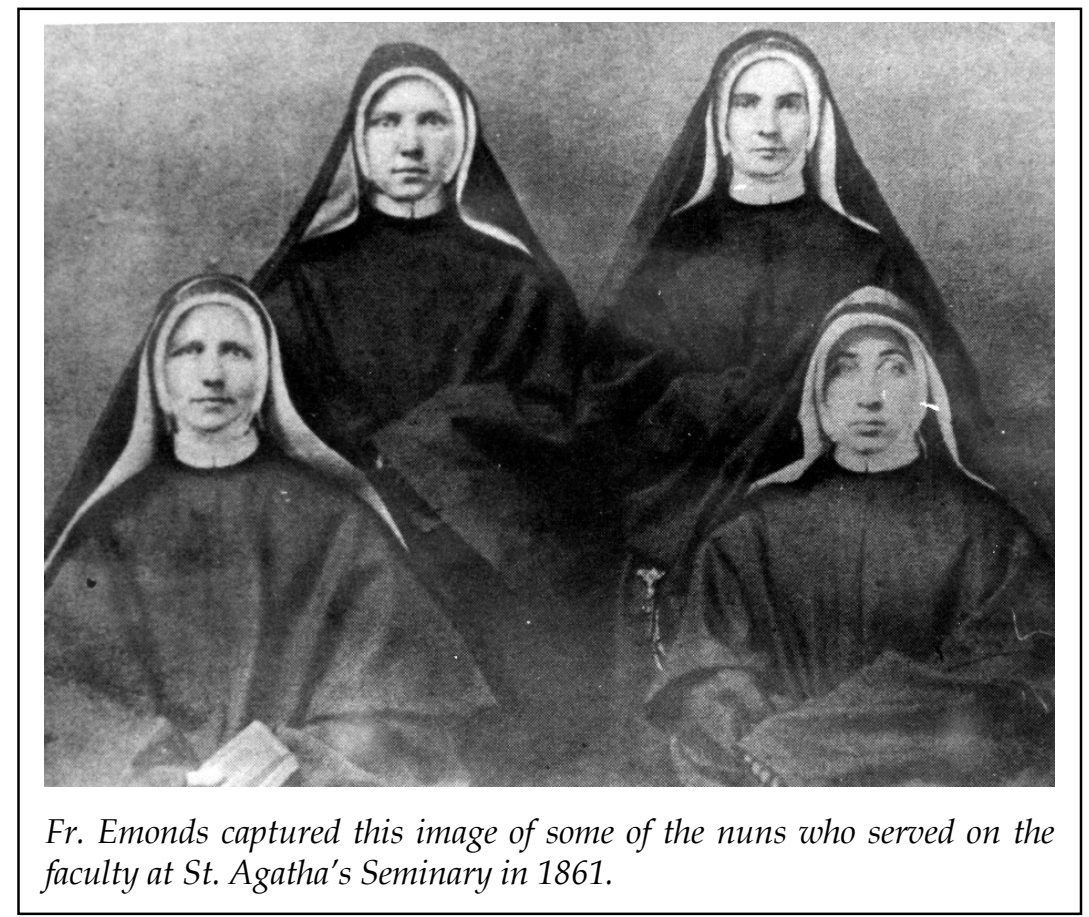

the Germans and the Czechs, departed from St. Mary's. They formed St. Patrick's Church in southern Iowa City, originally housed in a structure at Dubuque and Burlington streets that had previously hosted a public library, lecture hall, and several Protestant congregations. On February 2, 1879, they celebrated a first Mass at a new church at Linn and Court streets. St. Patrick's first four pastors, through 1915, were Irish-born. The Irish parish operated a school for boys, while girls from the parish were encouraged to attend St. Agatha's Seminary at Jefferson and Dubuque streets. The Sisters of Charity B.V.M., an order that originated with Franciscan sisters who had migrated from Ireland to the United States in the 1830s, staffed Iowa City's Catholic schools, including St. Mary's school. While Catholics of Irish heritage in Iowa City lacked the numerical dominance that they enjoyed in much of the urban northern United States, they participated in a larger American Catholicism that was dominated by Irish American clergy and that sought to defend communalistic Catholic 
distinctiveness amid the rapid urban growth and burgeoning individualistic capitalism of a historically Protestant nation. ${ }^{35}$

Long affected by their minority status among Iowa City Catholics behind the Germans and the Irish, Bohemians made their own departure from St. Mary's at the end of the nineteenth century. Led by a Czech priest, Joseph Sinkmajer (born in Lysá, near Prague, in 1866), who had ministered to them at St. Mary's, Bohemian Catholics departed in 1893 to form a new parish named in honor of the Bohemian patron saint, medieval aristocrat, and martyr St. Wenceslaus, in the Goosetown neighborhood in northern Iowa City, a working-class Czech enclave since the 1850s. When the cornerstone was laid on June 24, 1893, Sinkmajer preached in Czech, and Fr. John O'Farrell, pastor at St. Patrick's, preached in English, stressing the new parish's identity as a national parish for Czechs: "To-day my Bohemian brothers, you have raised a new Bethel. Here Bohemian Catholics and others will come to worship God for this will be a holy gate to heaven." 36

The parish sustained strong sentimental ties to the homeland, for instance raising 6,000 kronen $(\$ 1,224$, or about $\$ 33,160$ in 2016 dollars) for the relief of storm victims in Bohemia in September 1904. Inspired by the stirrings of Czech and Slavic nationalism in the late nineteenth century and the creation of an independent Czechoslovakia after the collapse of the AustroHungarian Empire following World War I, Czech American Catholics at St. Wenceslaus blended pride in a distinct ethnic heritage with the outward assimilation that post-World War I American culture demanded. ${ }^{37}$

35. Kenneth Patrick Michael Donnelly, St. Patrick's Church, Iowa City, Iowa, 1872-1972 (Iowa City, 1972), 1-22; Iowa City Daily Press, 12/9/1904; "Iowa City. St. Patrick's. The Rev. P. J. O'Reilly, Pastor," Catholic Messenger, 2/3/1938, p. 28; Fuhrmann, Souvenir of the Diamond Jubilee of St. Mary's Church, 67-76; Dolan, The Irish Americans. For the history of St. Agatha's Seminary, see Jordan Archer, "Historic Iowa City Women's Seminary Paves the Way Toward Equal Access to Education," Little Village, 12/6/2016.

36. Centennial, St. Wenceslaus Church, Iowa City, Iowa, 1893-1993 (Iowa City, 1993).

37. The Catholic Church in the United States of America: Undertaken to Celebrate the Jubilee of His Holiness, Pope Pius X (New York, 1914), 607; Iowa Citizen, 6/24/ 1893, 6/26/1893 (quotation); Iowa City State Press, 9/5/1903; "The Debt Wiped Out," Iowa Catholic Messenger, 2/27/1897, p. 5; Cada, Czech-American Catholics. 


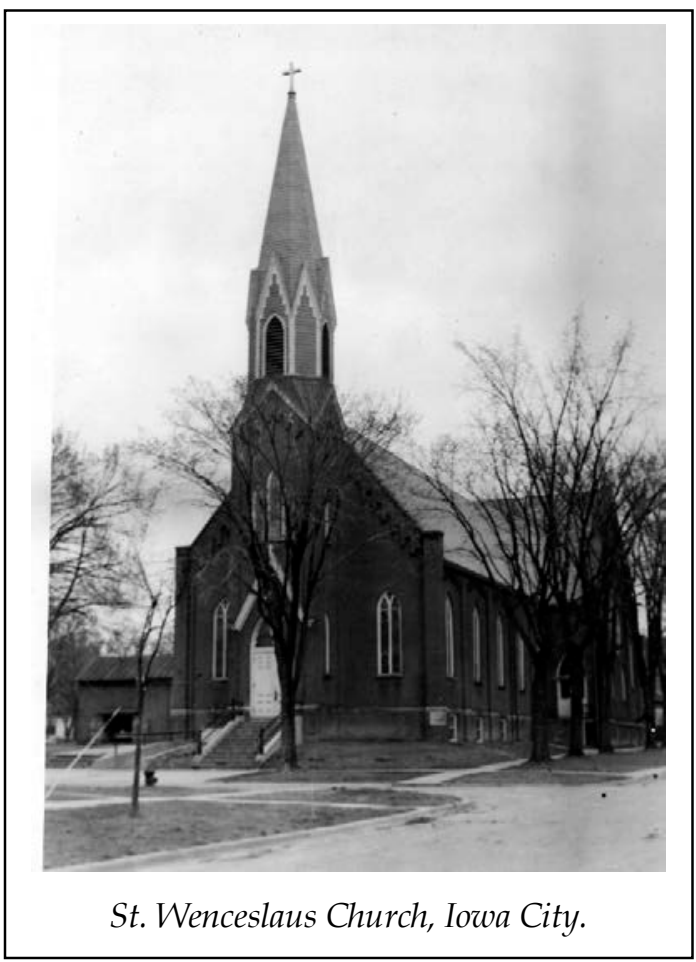

BACK AT ST. MARY'S, following the exodus of many Irish and Czech parishioners, the latter nineteenth century would see the elaboration of a tentative German Catholic sensibility, a diasporic devotional consciousness shaped by the Kulturkampf, the anti-Catholic policies of Prussian Prime Minister Otto von Bismarck. ${ }^{38}$ Unlike many midwestern urban and rural parishes with substantial German congregations, however, St. Mary's would never become a fully German national parish. There were several reasons for that: ethnic primacy had been contested there for decades; the congregation was always mixed and never exclusively German; English had long been the primary language of the parish; and Iowa City's Germans were comparatively assimilated by the time German Catholics became the dominant group in the parish in the late nineteenth century.

38. For a succinct treatment of the political and religious contexts for the Kulturkampf, see Steven Ozment, A Mighty Fortress: A New History of the German People (New York, 2004), 214-20. 
German Catholics in Iowa City had initially strongly resisted the leadership of German-born pastor William Emonds. Yet in the 30 years of his pastorate, he traveled periodically to AustriaHungary and Germany, where he purchased the Stations of the Cross that he installed on the walls at St. Mary's. In 1871 Emonds recruited nuns from his native German region of Westphalia, Prussia-Sisters of St. Francis fleeing Bismarck's repressive "May Laws" - to Iowa City, where he found them a residence in the former rectory of St. Francis Xavier Church. Decades spent navigating the fraught ethnic politics of American Catholicism in the Midwest and Pacific Northwest did not erase Emonds's ties to German-speaking lands. He returned to his native Germany for the last few years of his life, and he died in Cologne in 1903. ${ }^{39}$

During the lengthy pastorate at St. Mary's of A. J. Schulte, a German-American priest born in Ft. Madison (to a father who had emigrated from Haselünne, Hanover) who served from 1891 until his death in 1940, the parish underwent substantial expansion of its plant and also displayed a defensive assimilation that eventually sought to deny the persistence of Old World Teutonic traits, which in any case were more muted at St. Mary's than in many German-majority parishes across the Midwest. Yet the parish's German American identity was undeniable: in the early twentieth century, the surnames of many parishioners reflected German ancestry; traditional German songs were sung by oldtimers at parish events; Schulte delivered a sermon in German at the Mass in 1907 marking the 25th anniversary of his ordination;

39. Fuhrmann, Souvenir of the Diamond Jubilee of St. Mary's Church, 65, 86, 91; "Impressive Services of Requiem Held in St. Mary's Church, Iowa City for the Late Father Emonds," Catholic Messenger, 1/24/1907, p. 1. As a young priest prior to arriving in Iowa City, Emonds had confronted ethnic politics in Keokuk, where he ran into trouble for building St. Peter the Apostle Church in 1856 without the full approbation of Bishop Loras, and then faced disappointed German Catholics who had thought the new parish would be exclusively for Germans, while Loras insisted that it would serve a mixed congregation. In a trajectory similar to what occurred in Iowa City, German Catholics in Keokuk would form a national parish, St. Mary's, in 1867. John F. Kempker, "Catholicity in Southeastern (Lee County) Iowa," Records of the American Catholic Historical Society of Philadelphia, vol. 2, 1886-1888 (Philadelphia, 1889), 139. Emonds left St. Mary's in 1890 and went to the Pacific Northwest, where he built and pastored St. Patrick's Church in Tacoma, Washington. "Father Emonds Says Farewell," Catholic Messenger, 11/22/1890, p. 8. 


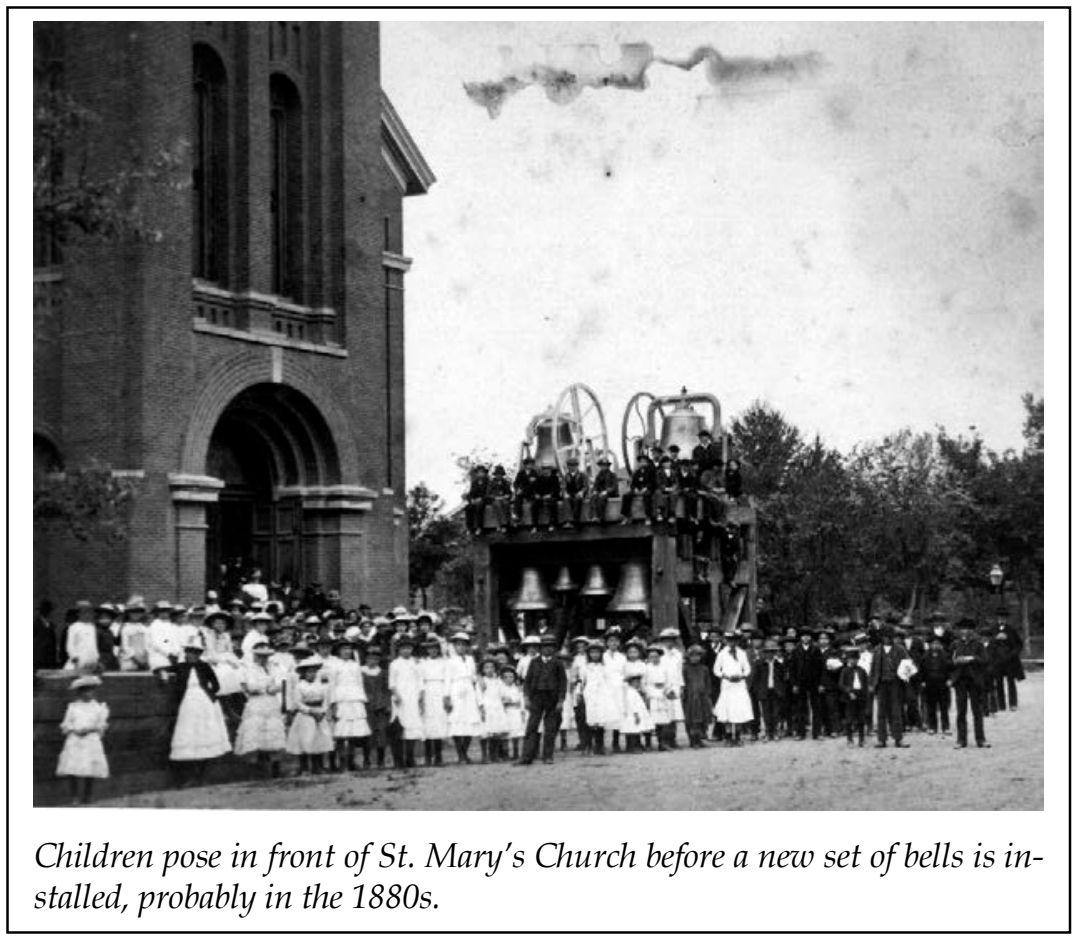

and Schulte was an active leader in the St. Boniface League of Iowa, an association of German Catholic societies. 40

Like many midwestern German Catholics and Lutherans in the era of the First World War and its aftermath, however, Fr. Schulte and St. Mary's participated in a larger German American tendency to suppress the German language and other aspects of lingering German distinctiveness in an era that insisted on "100 percent Americanism." For example, two years before Iowa Governor William L. Harding issued his infamous "Babel Proclamation," which forbade speaking any language other than English in public, a 1916 parish history downplayed the use of German in the parish, somewhat contradicting its own description of a lengthy history of German sermons and oratory by "German resident priests" at St. Mary's. During the war, even as some 


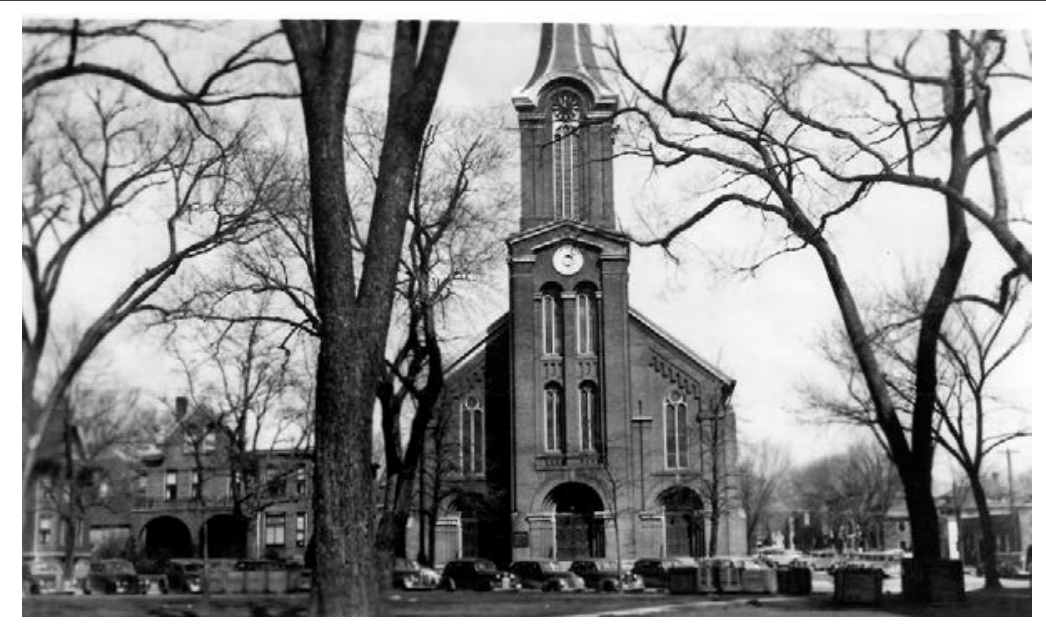

St. Mary's Church, Iowa City, ca. 1930.

questioned the allegiance of Catholics with ancestral ties to nations at war with the United States, such as Germany and AustriaHungary, Schulte and other Catholic leaders across eastern Iowa stressed their loyalty to the United States and their commitment, financial and otherwise, to the success of the American war effort. In the postwar period, Schulte expressed a traditional German American Catholic distaste for socialism that aligned well with the era's antiradicalism but fit less comfortably with the period's celebration of business culture and wealth creation. Speaking at the Iowa City Kiwanis Club in 1923 in a talk titled "Perils to our Democracy," the longtime pastor of St. Mary's decried left-wing ideologies but also argued that the "lavish and extravagant display of great wealth does much to fan the flames of socialism." 41

41. Fuhrmann, Souvenir of the Diamond Jubilee of St. Mary's Church, 91; Iowa City Daily Press, 10/6/1911; Nancy Derr, “The Babel Proclamation," Palimpsest 60 (1979), 100-101; Frederick C. Luebke, Bonds of Loyalty: German-Americans and World War I (DeKalb, IL, 1974); Iowa City Daily Citizen, 7/23/1917; Iowa City Citizen, 1/31/1916; Iowa City Press-Citizen, 10/9/1923. For German Catholics' antipathy to socialism and tendencies toward antistatism and communalism, see Conzen, "German Catholics in America," 580; Conzen, “Immigrant Religion and the Republic"; and Conzen, "Immigrant Religion in the Public Sphere." 
FURTHER CONSEQUENTIAL SHIFTS in the multiethnic cultures of Iowa City and midwestern Catholicism occurred in the following decades. By the mid-twentieth century in Iowa City, assimilative and Americanization pressures (hastened by a new emphasis by the church hierarchy on parishes organized along territorial rather than ethnic lines) eroded older ethnic separatism to the extent that participation as an individual believer in a larger American Catholicism eclipsed participation in worship as a member of an ethnic community of believers tied strongly to the place of ethnic origin or, eventually, even to a territorial parish. By the late twentieth century, even as Iowa Catholicism's multiculturalism deepened significantly with the in-migration of Catholics from Latin America and Asia bringing their own transnational Catholic cultures with distinct pastoral needs, the older cultural battles among ethnic Catholics that had so shaped the nineteenth-century texture of Iowa City Catholicism had faded to a distant, quaint memory. In 1991, as St. Mary's Church celebrated it sesquicentennial, parishioners held a series of ethnic-themed dinners in the parish hall, including German, Irish, French, Bohemian, Austrian, Italian, Korean, Chinese, and Mexican dinners. The ethnic dinners enacted an appreciation for the parish's diversity past and present, even as the notion of parish as ethnic enclave for particular European immigrant groups had long since lost relevance for most participants. ${ }^{42}$

42. For this process of cultural change among Catholics of German descent, see Conzen, "German Catholics in America," 582. For shifts more generally in American Catholicism in the twentieth century, see Orsi, "The Center Out There, in Here, and Everywhere Else, 213-32; Dolan, In Search of an American Catholicism, 180-89; Fisher, Communion of Immigrants, 114-33; Timothy Matovina, Latino Catholicism: Transformation in America's Largest Church (Princeton, NJ, 2011); Carl L. Bankston, III, "Vietnamese-American Catholicism: Transplanted and Flourishing," U.S. Catholic Historian 18 (2000), esp. 45-51; and Lalor, Celebrating Thanks!, 145-46. 